Check for updates

Cite this: RSC Adv., 2019, 9, 24670

\title{
Synergetic effects of $\mathrm{Cu} / \mathrm{TiO}_{2}$ sensitized with different cyanine dyes on hydrogen evolution $\uparrow$
}

\author{
Layla S. Almazroai ${ }^{a}$ and Rasha E. El-Mekawy (D)*ab
}

The production of hydrogen as an alternative fuel is a major challenge for developed countries. To achieve this, photocatalysis is a promising method, which depends mainly on a renewable energy source, namely, the sun. Many derivatives of cyanine-sensitized $\mathrm{Cu} / \mathrm{TiO}_{2}$ were prepared and characterized by XRD, SEMEDS, TEM, BET surface area and UV-vis spectrophotometry and their photocatalytic activity was studied. The study of hydrogen production over the sensitized photocatalysts confirmed the significant role of the dyes in the enhancement of hydrogen production. Dye molecules harness light radiation to produce strong oxidizing species, such as hydroxyl radicals, which in turn form hydrogen molecules. Combining sonolysis with photocatalysis processes proved that ultrasound waves inhibit the agglomeration of particles and maintain their surface area. This synergetic process increased the efficiency of hydrogen production by 7 times using photocatalysis only.

Received 22nd June 2019

Accepted 24th July 2019

DOI: $10.1039 / \mathrm{c} 9 \mathrm{ra04696h}$

rsc.li/rsc-advances

hydrogen production over $\mathrm{Co} / \mathrm{TiO}_{2}$ reached $77.8 \%$ of that of $\mathrm{Pt} /$

\section{Introduction}

Since the innovative photoelectrochemical cell created by Fujishima and Honda using titanium oxide $\left(\mathrm{TiO}_{2}\right)$ was used in water splitting in $1972,{ }^{1}$ there have been many attempts to design simple, commercial, and viable photocatalytic reactions to produce hydrogen or remove pollutants. Exhaustive studies in the field of photocatalysis have shown various fascinating applications of photocatalytic reactions based on the use of semiconductors, such as $\mathrm{TiO}_{2}, \mathrm{Fe}_{2} \mathrm{O}_{3}, \mathrm{ZnO}, \mathrm{ZrO}_{2}, \mathrm{SnO}_{2}$ and $\mathrm{CdS} .^{2-4}$ Much work has focused on $\mathrm{TiO}_{2}$ because the potentials of its valence band (VB) and conduction band (CB) are straddled between the potentials of oxygen and hydrogen production, respectively. However, its efficiency of conversion is very low due to electron/hole $\left(\mathrm{e}^{-} / \mathrm{h}^{+}\right)$ recombination and low harvesting of solar radiation. Metal loading, metal doping, non-metal doping, ${ }^{5-12}$ and sensitizing of $\mathrm{TiO}_{2}$ with dyes $^{13-15}$ are some effective ways to fabricate new colored photocatalysts with high efficiency. Many metals, such as $\mathrm{Pt}, \mathrm{Pd}, \mathrm{Au}$, and $\mathrm{Rh}$, exhibit good activity in hydrogen production. Electron spin resonance (ESR) signals confirmed that the excited electron in the $\mathrm{CB}$ of $\mathrm{TiO}_{2}$ transfers to the Fermi levels of the loaded metal, increasing the lifetime of the generated electron and hole. ${ }^{16}$ Attention has been focused on non-noble metals, such as $\mathrm{Cu}$ and $\mathrm{Sn}$, which display significant enhancements in water splitting in the presence of sacrificial reagents $\left(20\right.$ and 44 times that of $\mathrm{TiO}_{2}$, respectively ${ }^{7,17-20}$ ). Compared with precious noble metals, the rate of

${ }^{a}$ Department of Chemistry, Faculty of Applied Science, Umm Al-Qura University, Makkah, Saudi Arabia.E-mail: rashachemistry1@yahoo.com

${ }^{b}$ Department of Petrochemicals, Egyptian Petroleum Research Institute, Nasr City, Cairo, Egypt

$\dagger$ Electronic supplementary information (ESI) available. See DOI: $10.1039 / \mathrm{c} 9 \mathrm{ra} 04696 \mathrm{~h}$
$\mathrm{TiO}_{2}{ }^{21}$ Metal-loaded $\mathrm{TiO}_{2}$ is not sufficient to afford reasonably efficient hydrogen production from pure water. In recent years, dye sensitization has become a promising way to activate $\mathrm{TiO}_{2}$ under visible light in hydrogen production. ${ }^{13-22}$ The electrons are injected into the $\mathrm{CB}$ of $\mathrm{TiO}_{2}$ from the lowest unoccupied molecular orbital (LUMO) of the sensitized dye, which has higher energy than the $\mathrm{CB}$ edge of $\mathrm{TiO}_{2}$. In contrast, the efficiency of dyes without semiconductors is very low. Dye-sensitized solar cells have higher conversion efficiencies than plant photosystems, although there is a theoretical limit of $c a .30 \%$ to their efficiency. ${ }^{23}$ The highest known conversion efficiency of $15 \%$ was achieved in a solar cell that employed an organic-inorganic hybrid perovskite $\left(\mathrm{CH}_{3} \mathrm{NH}_{3} \mathrm{PbI}_{3}\right)$ as a sensitizing dye. ${ }^{24}$

One of the most important types of dye is cyanine dyes. Cyanine dyes have made great impressions in many different fields internationally; hence, it is important to study their photochemical and photophysical properties. ${ }^{25-27}$ This importance is a result of the nature of the chemical structure of these dyes, as they are among the most sensitive optical materials. ${ }^{28}$ They are known as fluorophores and are fundamentally recognized by their UV-vis absorption and fluorescence spectra, molar extinction coefficients, quantum efficiencies, and Stokes shifts. ${ }^{28-31}$ In this research article, the features of pure chromophoric dyes and numerous pathways for their design towards higher efficiency as catalysts in photo- and sono-catalysis are explored.

Enhancement of hydrogen production is not limited to modification of the photocatalyst, but also focuses on the techniques used in the process. Recently, a promising technique has exhibited good results regarding the efficiency of oxidation processes on photocatalysts. The sonophotocatalysis process is a combination of photocatalysis with sonolysis. ${ }^{32-35}$ 
The ultrasound may decrease the particle size and increase the mass transfer. Moreover, it influences surface cleaning. ${ }^{36}$ Sonolysis implies the generation of very high heat (around 5000 K) from cavity implosion because water decomposes to $\mathrm{H}_{2} \mathrm{O}_{2}$ and $\mathrm{H}_{2}$ when it is irradiated with ultrasound waves. ${ }^{37}$ In contrast, the photocatalysis technique produces little or no hydrogen evolution under special conditions. Surprisingly, water was decomposed to hydrogen and oxygen simultaneously in the liquid phase by sonophotocatalysis. ${ }^{35}$ In this article, four new derivatives of cyanine that incorporate $\mathrm{Cu} / \mathrm{TiO}_{2}$ were investigated to improve the rate of hydrogen production in the visible light region, which represents $95 \%$ of sun radiation. A comparison of the efficiencies of these samples when used in photocatalysis and sonophotocatalysis was achieved.

\section{Results and discussion}

\section{Chemistry of cyanine derivatives}

It is useful to list a new series of long-lasting cyanine dyes, which have distinct application effects and are leaving a distinctive mark in the field of renewable energy; therefore, we focused our thinking on preparing an innovative series of cyanine dyes. Initially, 3-(2-benzylpyridin-1-ium-1-yl)propane-1sulfonate (2) was synthesized by the reaction of benzylpyridine with carefully chosen blocking groups which can be attached to the nitrogen atom of pyridine, such as propanesultone in freshly distilled toluene under reflux for $4 \mathrm{~h}$ under nitrogen gas. This reaction was carried out in a Dean-Stark apparatus; these conditions allowed the system to be run in the absence of air and water, as depicted in Scheme 1.

The structure of quaternary ammonium salt 2 was elucidated by ${ }^{1} \mathrm{H}$ NMR spectroscopy. This spectrum showed quintet signals at $\delta 1.67 \mathrm{ppm}$, which are attributable to the middle methylene protons of the sultone chain, and two triplet signals at $\delta 2.75$ and $3.51 \mathrm{ppm}$ corresponding to the $\underline{\mathrm{CH}}_{2}-\mathrm{SO}_{3}$ and $\underline{\mathrm{CH}}_{2}$ propane $-\mathrm{N}^{+}$protons in addition to a singlet signal at $\delta 3.70 \mathrm{ppm}$, which is due to the $\mathrm{CH}_{2}$ protons of the benzyl group. The mass spectrum of 2 exhibited a molecular ion peak at $\mathrm{m} / \mathrm{z}=$ $291\left(\mathrm{M}^{+}, 47 \%\right)$ corresponding to the molecular formula $\mathrm{C}_{15} \mathrm{H}_{17} \mathrm{NO}_{3} \mathrm{~S}$. Additionally, the ${ }^{13} \mathrm{C}$ NMR spectrum provided further confirmation of the chemical structure of 2 .

Modulation of cyanine dyes is possible through various strategies; for example, the symmetrical amalgamation of $\pi$ -

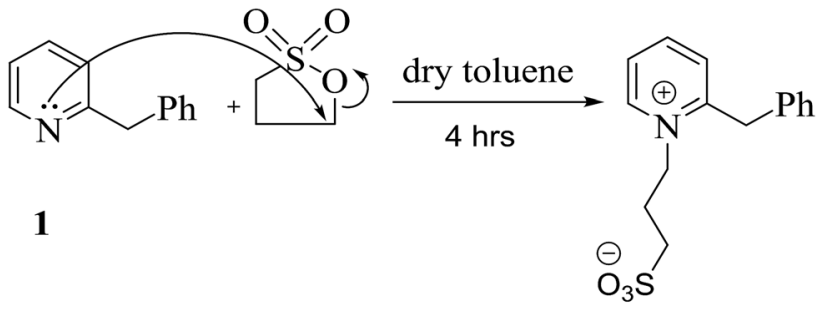

2

Scheme 1 Designation of the quaternary nitrogen incorporated in the pyridine ring. conjugated bridges such as $\mathrm{N}$-[5-anilino-3-chloro-2,4-(propane1,3-diyl)2,4-pentadiene-1-ylidene]anilinium chloride ${ }^{38}$ with two units of quaternary ammonium salt 2 yielded heptamethine cyanine dye 5, which acted as a precursor for the formation of other analogues. Near-infrared (NIR) chromophore 5 was produced by two pathways. One is a straightforward two potcomponent synthesis, where compound $\mathbf{3}$ is combined with two moles of pyridinium salt 2 by refluxing for $3.5 \mathrm{~h}$ in the presence of absolute ethanol, acetic anhydride as the solvent, and sodium acetate as a basic catalyst under nitrogen gas. Acetic anhydride serves as a solvent and also effectively inhibits the polymerization of polyconjugated system 3 . The other pathway involves heating one mole of compound 2 with 3 in the presence of $n$-butanol and benzene in a ratio of $7: 3$ for 2 to $5 \mathrm{~h}$, resulting in hexamethine cyanine dye $\mathbf{5}$ in good yield; this is converted to 5 by refluxing with one mole of compound 2 in pyridine for $3 \mathrm{~h}$, as outlined in Scheme 2. Compound 5 was elucidated based on its correct analytical and spectral data. The assignment of the ${ }^{1} \mathrm{H}$ NMR spectrum showed four triplet signals at $\delta 1.79\left(\mathrm{C} 4-\mathrm{H}_{2}\right.$ and $\mathrm{C} 6-\mathrm{H}_{2}$ of the cyclohexenyl protons $), 2.11$ (two $\left.\mathrm{CH}_{2}-\mathrm{SO}_{3}\right), 2.74\left(\mathrm{CH}_{2}-\mathrm{N}\right)$, and $4.1\left(\mathrm{CH}_{2}-\mathrm{N}^{+}\right)$ppm. On the other hand, the ${ }^{1} \mathrm{H}-\mathrm{NMR}$ spectrum revealed no singlet signal at $\delta 3.70 \mathrm{ppm}$ due to $\mathrm{CH}_{2}$ of the benzyl group and instead showed two new singlet signals which appeared at $\delta 4.40$ and $6.36 \mathrm{ppm}$; these are due to the two $=\mathrm{CH}$ protons.

The chlorine atom at the meso position of conjugated system 5 underwent a nucleophilic substitution reaction with another nucleophilic moiety. The following protocols are based on the methods dedicated to or recommended for synthesizing different members of the heptamethine cyanine dye family that become excited in the NIR region. Chromophore 5 was a sensible candidate for constructing the efficient light harvesting cyanine dye 6 via heating under reflux with one molar ratio of piperazine in $N, N$-dimethylformamide and sodium hydroxide as a catalyst for $5 \mathrm{~h}$ under nitrogen gas. Two units of compound 5 were linked by reacting two units of structure 5 with one mole of piperazine via two nucleophilic substitution reactions of two chlorine atoms at the meso position of 5 to produce the heptamethine cyanine dye dimer 7. Alternatively, chromophore 6 was refluxed under nitrogen gas to avoid air bubbles or moisture from the reaction in the presence of sodium hydride and $N, N$-dimethylformamide to form compound 7. The chemical structure of compound 6 was confirmed based on its spectral and elemental analyses. The IR spectrum showed an absorption band at $\dot{U}=3453 \mathrm{~cm}^{-1}$ corresponding to the $\mathrm{NH}$ functional group. On the other hand, the ${ }^{1} \mathrm{H}$ NMR spectrum displayed a characteristic singlet signal at $\delta=$ $12.10 \mathrm{ppm}$ due to the $\mathrm{NH}$ proton; however, this disappeared in the ${ }^{1} \mathrm{H}$ NMR spectrum of compound 7, which gave evidence for its consumption in the formation of the dimer. Another cyanine dye, $\mathbf{8}$, was produced by several possible pathways; 1,6-hexadiol was reacted with compound 5 by removing $\mathrm{HCl}$ during refluxing in the presence of sodium hydroxide and $N, N$-dimethylformamide in a closed system to avoid air and moisture. However, two linked moles of compound 5 underwent a reaction with 1,6hexadiol by two nucleophilic reactions of two hydroxyl groups and two chlorin groups, affording heptamethine cyanine dye 

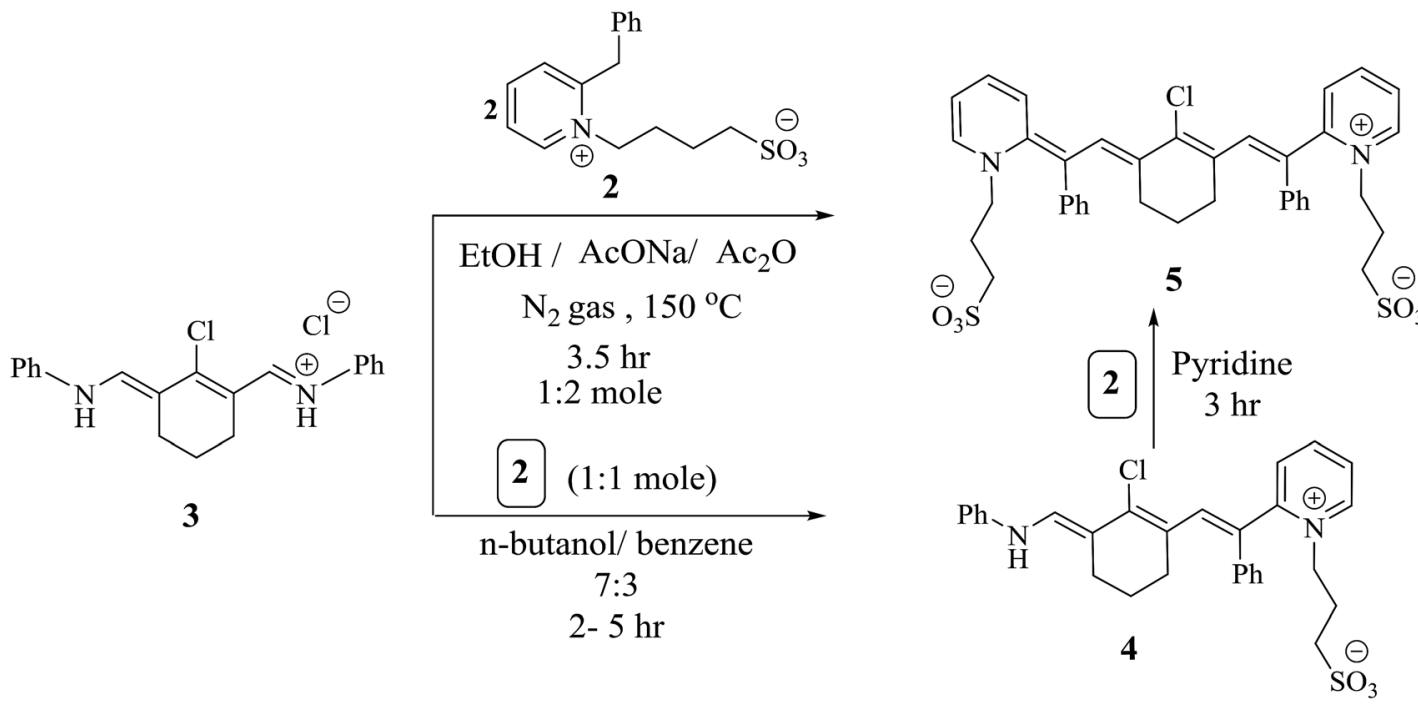

Scheme 2 Utilizing alternate pathways for the formation of heptamethine cyanine dye 5 .

dimer 9, which can be synthesized by an alternate method. When compound $\mathbf{8}$ reacted with one mole of compound $\mathbf{5}$ in the presence of sodium hydride as a base and $N, N$-dimethylformamide as the solvent under nitrogen gas, structure 9 was obtained and subjected to spectral and elemental analyses. The IR spectrum showed no absorption band at $\dot{U}=3412 \mathrm{~cm}^{-1}$; this indicates that the hydroxyl group disappeared. Also, this fact is elucidated by the ${ }^{1} \mathrm{H}$ NMR spectrum, which revealed no absorption band at $\delta=11.63 \mathrm{ppm}$ due to the $\mathrm{OH}$ proton. All of these data confirm the chemical structure of dimer 9 (Scheme 3).

\section{Physical properties of cyanine derivatives and sensitized $\mathrm{Cu} /$ $\mathrm{TiO}_{2}$}

Heptamethine cyanine dyes are characterized by tunable long wavelength absorption and emission due to their long $\pi$ conjugated systems. These dyes possess a wide response spectrum, high extinction coefficients $\left(>200000 \mathrm{l} \mathrm{mol}^{-1} \mathrm{~cm}^{-1}\right)$, good fluorescence, and high photostability. Synthetic chromophores $^{39,40}$ are known to absorb between the visible and infrared zones of the electromagnetic spectrum. NIR fluorescent cyanine dyes 6, 7, 8 and 9 display absorption bands at $\lambda_{\max }=639,649$, 648 and $650 \mathrm{~nm}$ but appear in expanded emission frequencies in the NIR-region at $\lambda_{\max }=666,674,670$ and $675 \mathrm{~nm}$. It was observed that compounds 7 and 9 show one absorption band, which indicates the planarity of the two joint units of delocalized conjugated systems in space; in addition, the ${ }^{1} \mathrm{H}$ NMR spectrum showed one signal for the same protons in each unit. The collected data of the UV-vis spectra showed that the photosensitization of these dyes increases as the conjugation increases. This leads to increasing delocalization of the expanded $\pi$-system because the resonance between the two nitrogen atoms of the pyridinium and pyridine rings increases, while the energy gap between the HOMO and LUMO decreases and the excitation energy decreases. This factor leads to the liberation of a large current of electrons and appears to be essential for charge transfer during excitation from the ground state to the first excited state and the triplet excited state; this generates more singlet oxygen species, which are responsible for the reactivity of the molecules. Note that compounds 7 and 9 give high absorption bands with high absorption intensities due to the presence of two units of the conjugated system, causing bathochromic shifts toward the NIR region (Fig. 1(A)) (Table 1).

Dye-sensitized $\mathrm{Cu} / \mathrm{TiO}_{2}$ exhibited a much higher capacity for absorbance in the visible region than $\mathrm{Cu} / \mathrm{TiO}_{2}$, as shown in Fig. 1(B). The difference between the absorbance spectra of the different dye-sensitized $\mathrm{Cu} / \mathrm{TiO}_{2}$ photocatalysts was small. The stability of the synthesized photosensitizers was explained by thermal gravimetric analysis (TGA). TGA gave fruitful results regarding the excellent stability of compounds 6, 7, 8 and 9, as depicted in Fig. 2. Firstly, moisture is liberated; then weight loss starts from breakage of the substituent at the meso position at high temperatures, which does not affect the conjugated system. This fact indicates the suitability of the compounds for application in the field of renewable energy.

SEM and EDS analyses of the cyanine dye derivative $\mathrm{Cu} / \mathrm{TiO}_{2}$ and dye-sensitized $\mathrm{Cu} / \mathrm{TiO}_{2}$ were performed. Fig. 3(A) displays the morphologies and the compositions of these dyes. The structures of the synthesized dyes 6, 7, 8 and 9 contain pores and active sites which provide areas for the delocalization of $\pi$ electrons; also, the continuous generation of a current of electrons aids the subsequent photosensitization to the triplet excited state, leading to continuous generation of singlet oxygen species. On the other hand, $\mathrm{Cu} / \mathrm{TiO}_{2}$ was smooth, spherical and crystalline in size before and after sensitization (Fig. 3(B)). The uniform distributions of the elements of the composites were clear in the elemental maps of dye-sensitized $\mathrm{Cu} / \mathrm{TiO}_{2}$. EDS spectra confirmed the immobilization of the dyes on $\mathrm{Cu} / \mathrm{TiO}_{2}$.

The spherical particles of $\mathrm{Cu} / \mathrm{TiO}_{2}$ before and after sensitization of the dye are also shown in the TEM images (Fig. 4). Some dark spots can be assigned to $\mathrm{Cu}$ due to the high electronic density of the 


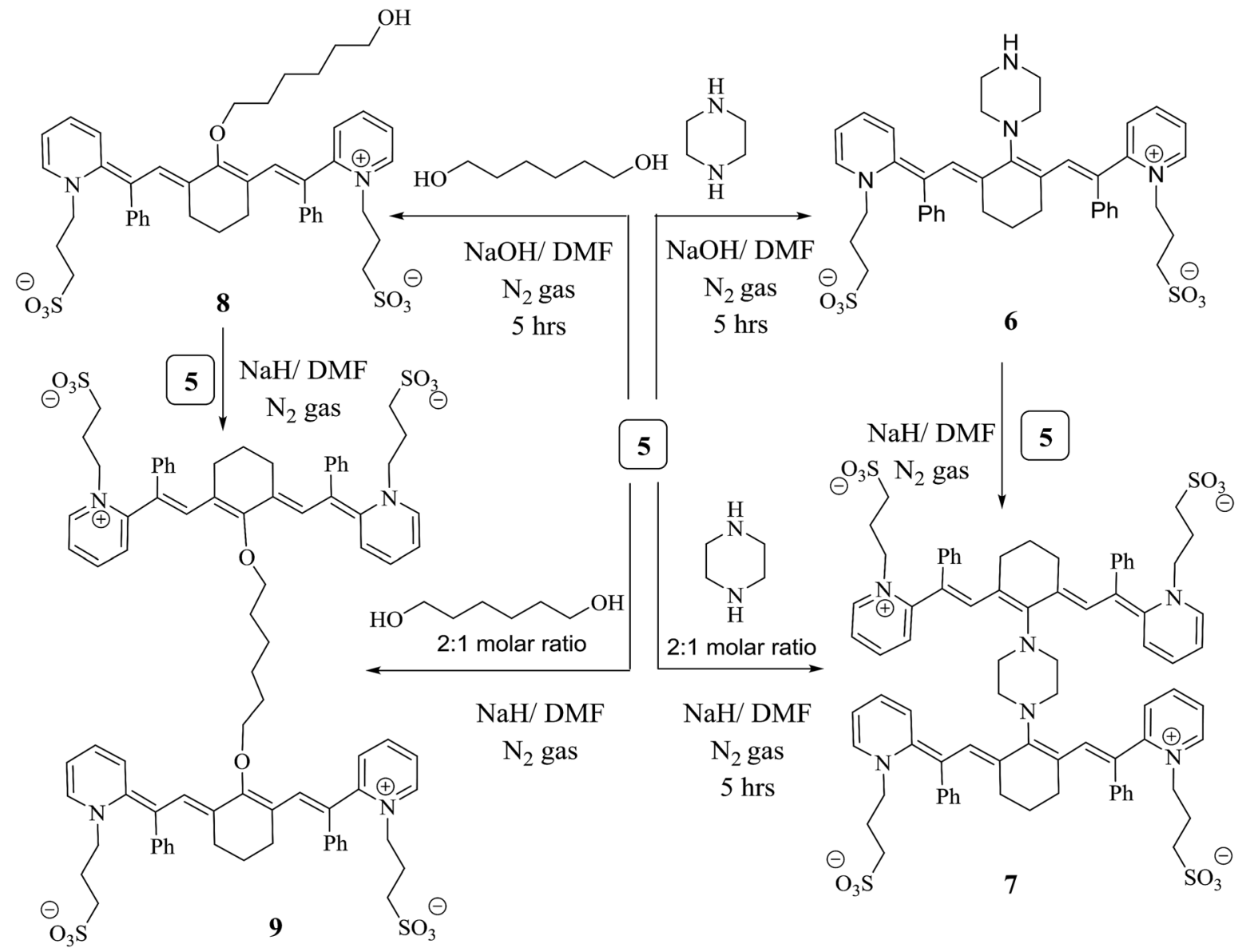

Scheme 3 Formation of heptamethine cyanine dye dimers.

metal. In contrast, the image after sensitization did not display a clear change because the dye molecules are organic and have low electronic density. However, EDX proved the existence of metal and dye molecules, as mentioned previously. The BET surface area of dye-sensitized $\mathrm{Cu} / \mathrm{TiO}_{2}$ was slightly higher than that of $\mathrm{Cu} / \mathrm{TiO}_{2}$, namely 16.1 and $14.3 \mathrm{~m}^{2} \mathrm{~g}^{-1}$, respectively.

\section{A}

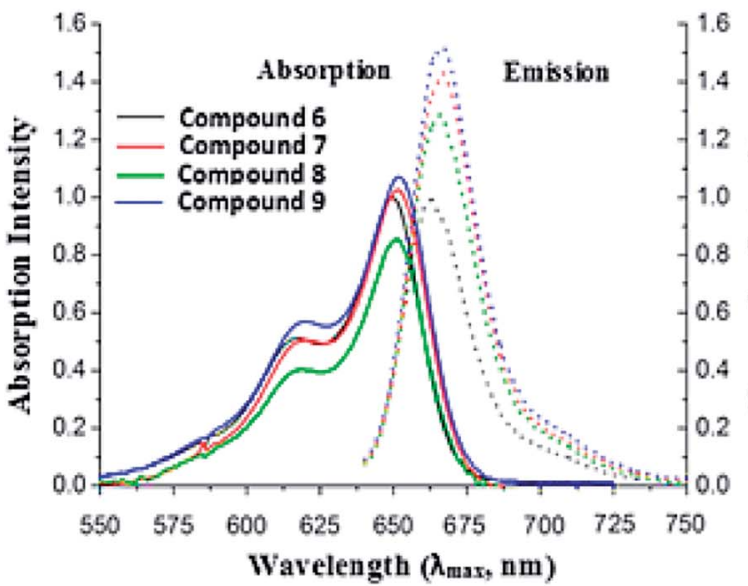

B

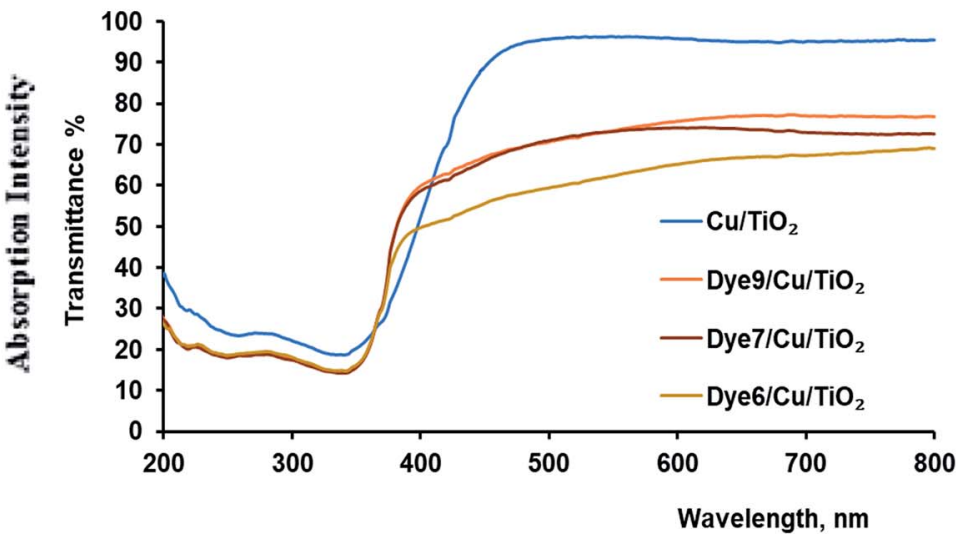

Fig. 1 (A) Absorption and emission bands of the chromophoric heptamethine carbocyanine dyes. (B) The transmittance\% spectra of dyesensitized $\mathrm{Cu} / \mathrm{TiO}_{2}$. 
Table 1 Electronic absorption and emission spectra of the newly prepared efficient chromophoric heptamethine carbocyanine dyes $6,7,8$ and 9

\begin{tabular}{|c|c|c|c|c|c|}
\hline 6 & 639 & 660 & 5.73 & 21 & 1.032 \\
\hline 7 & 649 & 674 & 5.63 & 25 & 1.038 \\
\hline
\end{tabular}

The XRD patterns of the different conjugated carbocyanine dyes $\mathbf{6}, 7,8$ and 9 displayed excellent crystallinity of their conjugated chemical structures, and the patterns of the derivatives of dye-sensitized $\mathrm{Cu} / \mathrm{TiO}_{2}$ are shown in Fig. 5. It is clear that the crystallinity of $\mathrm{TiO}_{2}$ did not change after doping with $\mathrm{Cu}$ and sensitizing of the dyes. The XRD spectra were in agreement with the standard $\mathrm{TiO}_{2}$ Degussa ${ }^{41}$ except for the rutile (110) peak at $2 \theta=28^{\circ}$ due to a phase transformation that occurred during metal doping. There were no peaks for $\mathrm{Cu}$ or the dye due to their low content, although EDS analysis confirmed their existence. Moreover, the positions of the peaks of $\mathrm{TiO}_{2}$ did not change, indicating that the doping of $\mathrm{Cu}$ occurred by a substitution process into the titania lattice instead of by interstitial incorporation. The crystalline size $D$ was calculated by the Scherrer equation:

$$
D=\frac{0.9 \lambda}{\beta \cos \theta}
$$

where $\lambda$ is the $\mathrm{X}$-ray wavelength corresponding to $\mathrm{Cu} \mathrm{K}$ radiation, $\beta$ is the full width at half maximum of the XRD peak, and $\theta$ is the diffraction angle. Table 2 shows the crystalline sizes of the samples.

\section{Photocatalytic activity of dye-sensitized $\mathrm{Cu} / \mathrm{TiO}_{2}$ in hydrogen evolution}

Hydrogen evolution over the catalysts before and after sensitization under UV and visible light was investigated, as shown in Fig. 6. The photocatalytic activity of $\mathrm{Cu} / \mathrm{TiO}_{2}$ was very low compared with those of the catalysts with absorbed dyes. This result agreed with previous studies. ${ }^{42,43}$ The order of
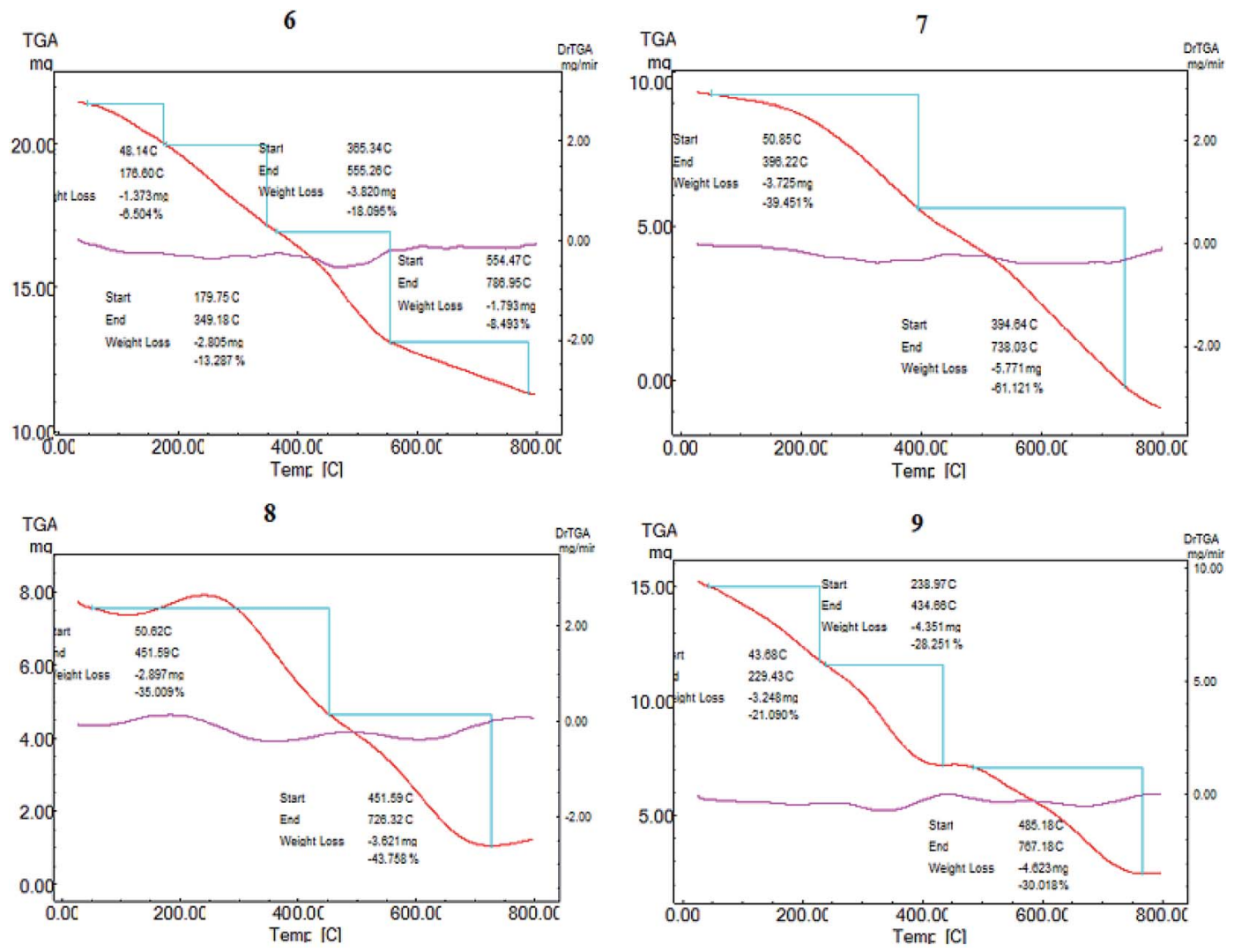

Fig. 2 Thermal gravimetric analysis of the novel effective photosensitizers 6, 7, 8 and 9. 

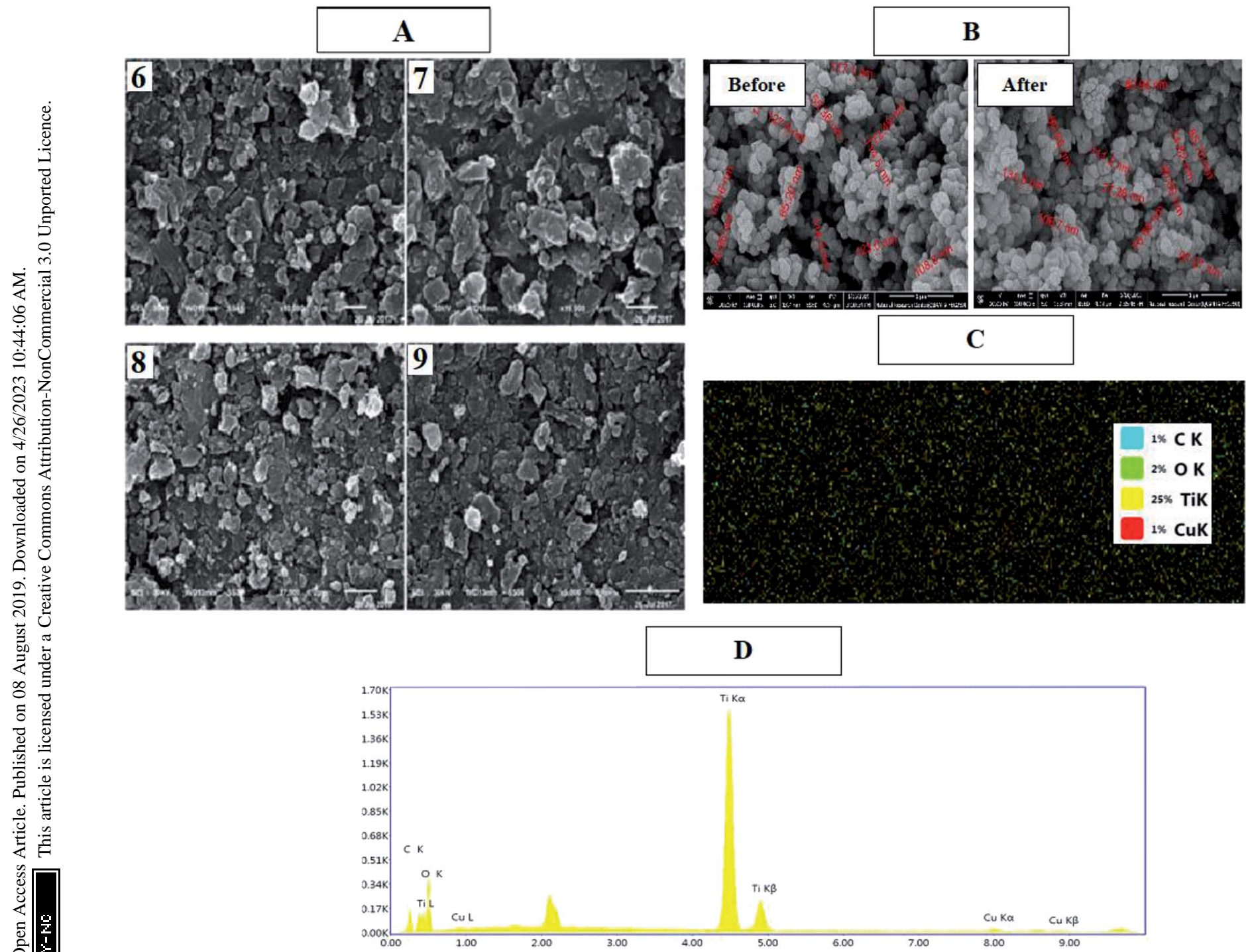

Fig. 3 SEM images of dyes $6,7,8$, and 9 (A) and $\mathrm{Cu} / \mathrm{TiO}_{2}$ before and after sensitization (B), EDS mapping of dye sensitized $\mathrm{Cu} / \mathrm{TiO}{ }_{2}(\mathrm{C})$, and $\mathrm{EDS}$ elemental analysis of dye $9 / \mathrm{CuTiO}_{2}$ (D).
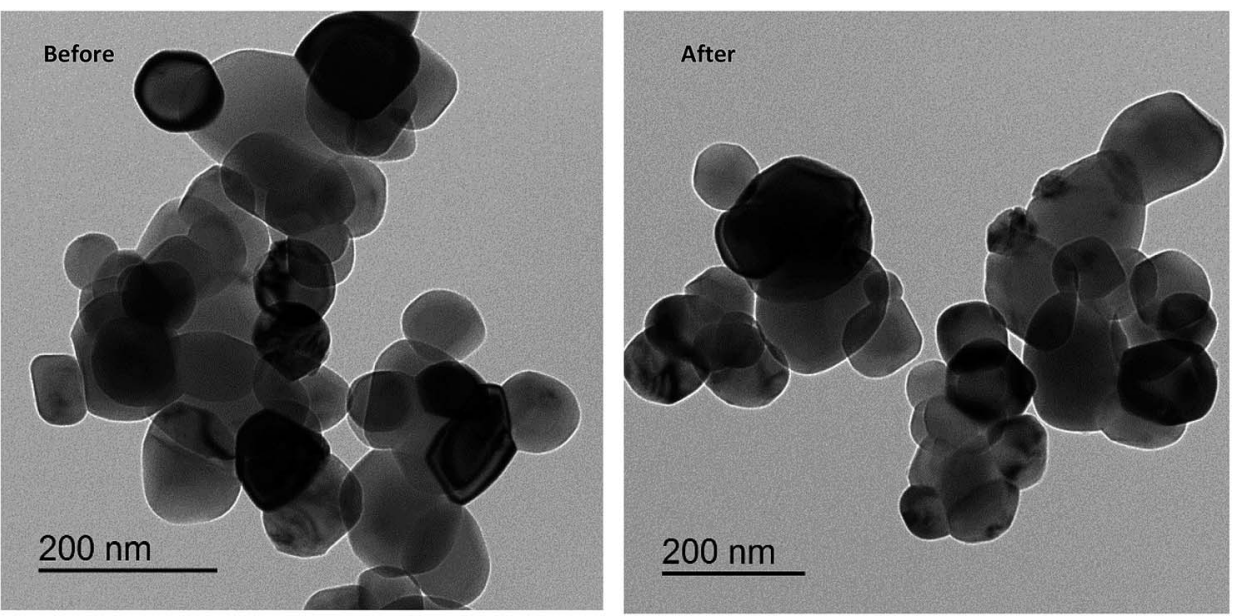

Fig. 4 TEM images of $\mathrm{Cu} / \mathrm{TiO}_{2}$ before and after dye sensitization. 

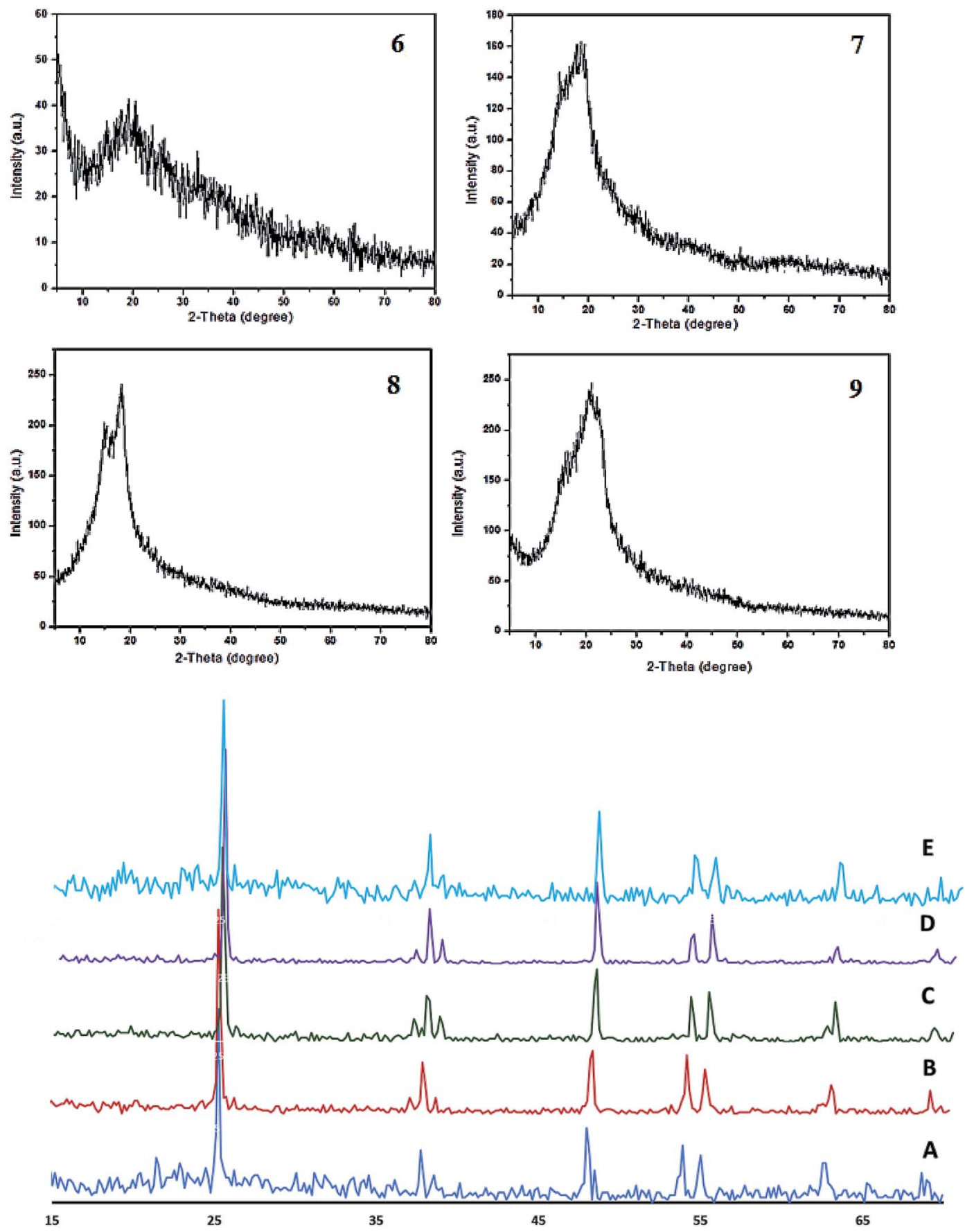

Fig. $5 \mathrm{X}$-ray diffraction patterns of heptamethine cyanine dyes $6,7,8$ and 9 (top) and of $\mathrm{Cu} / \mathrm{TiO}_{2}(\mathrm{~A}), 9 / \mathrm{Cu} / \mathrm{TiO} 2$ (B), 8/Cu/TiO 2 (C), 7/Cu/TiO 2 (D), and (E) $6 / \mathrm{Cu} / \mathrm{TiO}_{2}$ (bottom).

photocatalytic activity of the dye derivative-absorbed $\mathrm{Cu} / \mathrm{TiO}_{2}$ samples was $9>6>7>8$. The structure of these sensitizers influenced their photoactivity. Although 9 and 7 had high absorption intensity due to their highly conjugated systems, 9 was more active than 7 , and the latter was less active than $\mathbf{6}$. The structure of 7 suffers from steric hindrance and rigidity, which may increase the opportunity of aggregation and lead to increased possibility of aggregation of $\mathrm{Cu} / \mathrm{TiO}_{2}$ particles in general. ${ }^{4-46}$ The particle size of the catalyst with 7 was greater than that of the catalysts with 9 and 6. Dye 8 -sensitized $\mathrm{Cu} / \mathrm{TiO}_{2}$ with a particle size of $54.4 \mathrm{~nm}$ had the lowest activity and lowest absorption intensity. However, the enhancement of the photoactivity of the sensitized metal oxides was attributed to the high extinction coefficients of the dyes, which is a measure of the strength of the light absorbance.

The mechanism of hydrogen production over sensitized catalysts has been proposed in many studies. ${ }^{13}$ The first step is excitation of the dye molecule by the irradiation of light. The 
Table 2 Particle sizes of $\mathrm{Cu} / \mathrm{TiO}_{2}$ and the dye-sensitized $\mathrm{Cu} / \mathrm{TiO}_{2}$ samples

\begin{tabular}{ll}
\hline Sample & Particle size (nm) \\
\hline $\mathrm{Cu} / \mathrm{TiO}_{2}$ & 35.7 \\
Dye $9-\mathrm{Cu} / \mathrm{TiO}_{2}$ & 83.6 \\
Dye $8-\mathrm{Cu} / \mathrm{TiO}_{2}$ & 54.4 \\
Dye $7-\mathrm{Cu} / \mathrm{TiO}_{2}$ & 88.7 \\
Dye $6-\mathrm{Cu} / \mathrm{TiO}_{2}$ & 83.5
\end{tabular}

LUMO energy level of the dye is usually above the CB of $\mathrm{TiO}_{2}$. Therefore, the excited electron transfers from the excited dye molecule to the CB of $\mathrm{TiO}_{2}$. Then, this electron may be trapped by a $\mathrm{Cu}$ atom; the SEM images show the uniform dispersion of $\mathrm{Cu}$ over $\mathrm{TiO}_{2}$. This process inhibits the recombination of the $\mathrm{e}^{-/}$ $\mathrm{h}^{+}$pair and increases the time of their separation. ${ }^{47}$ The excited electron forms hydroxyl radicals, leading to the production of a hydrogen gas molecule. On the other hand, the hole formed at the HOMO of the dye is consumed by the oxidation of the sacrificial reagent, forming $\mathrm{H}_{2}$ gas. ${ }^{48,49}$ Although $\mathrm{TiO}_{2}$ absorbs light, its absorbance is restricted to the UV region, which has very low intensity in the spectrum of the Xe lamp. Moreover, the bulk and surface $\mathrm{e}^{-} / \mathrm{h}^{+}$recombination of $\mathrm{TiO}_{2}$ is one of the reasons that scientists tend to view the sensitization process as a promising solution. Fig. 7 shows a schematic of one of the suggested mechanisms.

Synergistic effect on the rate of hydrogen evolution, which is a combination of ultrasound waves and light radiation, was investigated. The results shown in Fig. 8 confirm the positive effects of ultrasound waves in preventing the agglomeration or aggregation of particles over time. Moreover, hydroxyl radicals were formed by the photocatalysis process by excited electrons and by the collapse of bubbles because of the ultrasound waves. The comparison between photocatalytic and sonophotocatalytic hydrogen production after 5.5 hours is plotted in Fig. 9. The

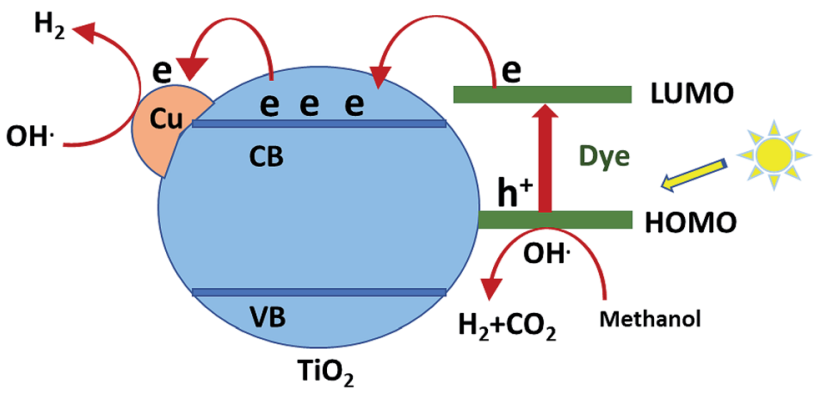

Fig. 7 Schematic of the suggested mechanism of $\mathrm{H}_{2}$ production over sensitized $\mathrm{Cu} / \mathrm{TiO}_{2}$.

synergistic effect increased the amount of hydrogen produced after 5.5 hours by about 7 times.

The effects of different amounts of the catalyst on the rate of photocatalytic hydrogen production were investigated, as shown in Fig. 10. It is logical that increasing the amount of the catalyst would increase the surface area for the oxidationreduction reaction and consequently increase hydrogen production. Irradiation of more than $0.14 \mathrm{~g}$ of the catalyst lowered the rate of hydrogen production due to the shielding effect by the particles. ${ }^{50,51}$

\section{Experimental}

\section{Characterization}

Melting degrees were uncorrected in degrees centigrade and tested on a Gallenkamp electric melting point instrument. The infrared (IR) spectra were detected (KBr disks) on a Mattson 5000 FTIR (Fourier transform infrared) spectrometer, the ${ }^{1} \mathrm{H}$ NMR and ${ }^{13} \mathrm{C}$ NMR spectra were determined using a Bruker WPSY $200 \mathrm{MHz}$ spectrometer with TMS as an internal standard, and the chemical shifts were measured in $\delta$ ppm using solvents such as DMSO- $d_{6}$ and/or $\mathrm{CDCl}_{3}$ at the Faculty of Science, Mansoura University, Egypt. The mass spectroscopy was

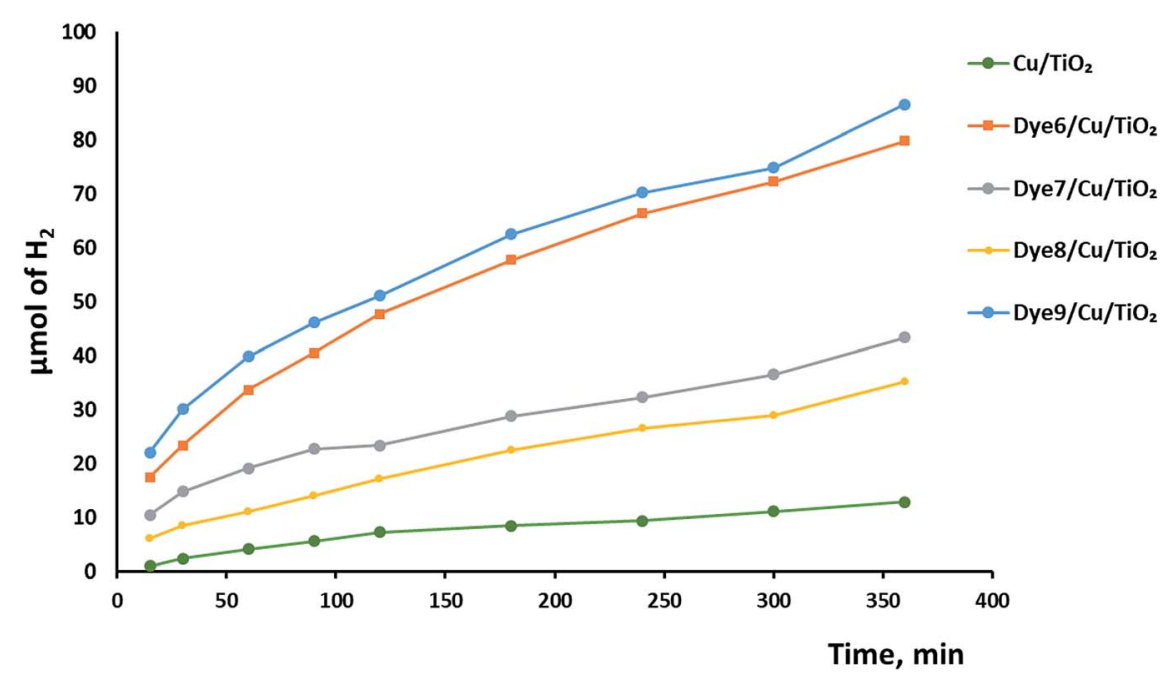

Fig. 6 The photocatalytic hydrogen production over dye-sensitized $\mathrm{Cu} / \mathrm{TiO}_{2}$. 


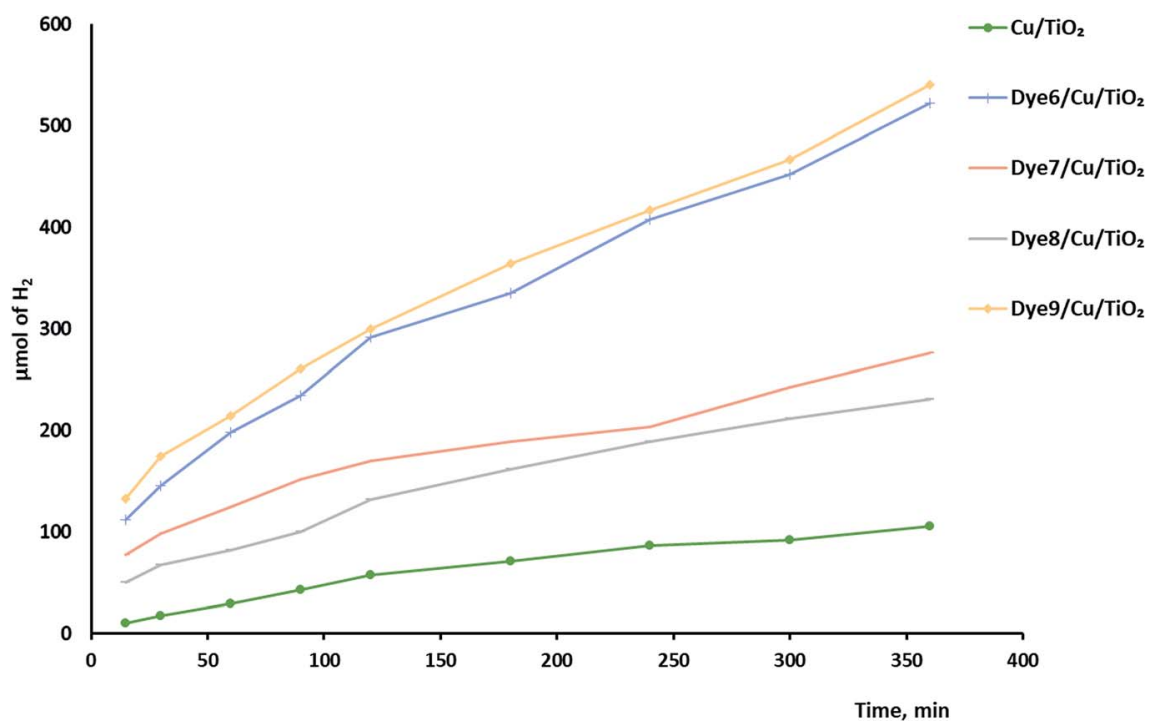

Fig. 8 Sonophotocatalytic hydrogen production over dye-sensitized $\mathrm{Cu} / \mathrm{TiO}_{2}$.

performed at $70 \mathrm{eV}$ with a Varian MAT 311 instrument, and elemental analyses (C, $\mathrm{H}$ and $\mathrm{N}$ ) were performed at the Microanalytical Center, Faculty of Science, Cairo University. The outcomes were in good approval $( \pm 0.03)$ with the studied rates. $\mathrm{X}$-ray diffraction (XRD) was employed to measure the crystallinity of the polymers. XRD was performed using a Philips model PW 3710 (Philips, USA) diffractometer with $\mathrm{CuK} \alpha$ radiation $(\lambda=0.1542 \mathrm{~nm})$ in a sealed tube operated at $40 \mathrm{kV}$ and 30 $\mathrm{mA}$. Energy dispersive X-ray spectrometry (EDS) and scanning electron microscopy (SEM) were performed using a Philips model XL 30CP, USA. The films were cut and mounted on a brass stub with double-sided adhesive tape and were coated with $50 \AA$ of gold vapor with an SCD-040 Balzers sputter. The specimen was finally characterized by SEM using an accelerating voltage of $30 \mathrm{kV}$ and $7500 \times 10000$ and 15000 magnification of the original specimen size.

4-(2-Benzylpyridinium-1-yl)propane-1-sulfonate (2). In a round-bottomed flask fitted with an air condenser and a Dean-Stark apparatus, a mixture of 2-benzylpyridine

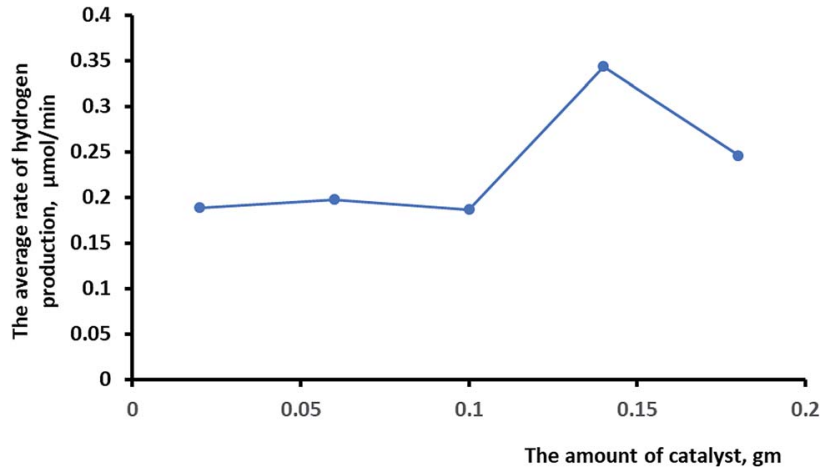

Fig. 10 The effects of the amount of catalyst on the rate of hydrogen production.

(1.69 g, $0.01 \mathrm{~mol}$ ) and 1,3-propanesultone (1.83 g, $0.015 \mathrm{~mol})$ was heated under reflux for $4 \mathrm{~h}$. The reaction mixture was then allowed to cool to room temperature. The resulting

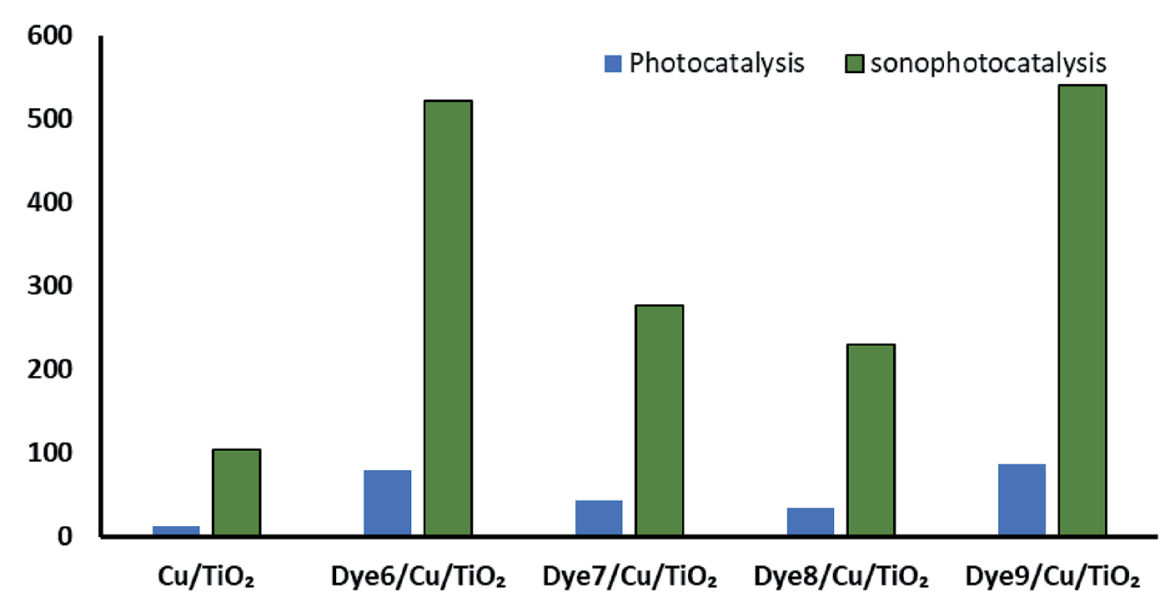

Fig. 9 Comparison between photo- and sonophotocatalytic hydrogen production. 
white crystals were filtered and washed with ether $(3 \times 15$ $\mathrm{ml}$ ). The filtered product was crystallized from a solution of methanol and diethyl ether.

Yield 89\%; white needle crystals; $\mathrm{mp} 152{ }^{\circ} \mathrm{C}$; IR (KBr): Ú $/ \mathrm{cm}^{-1}$ $=3101(\mathrm{Ar}-\mathrm{CH}), 2926\left(\mathrm{CH}_{2}\right), 1621(\mathrm{C}=\mathrm{N}), 1367,1151(2 \mathrm{~S}=\mathrm{O})$, $618(\mathrm{~S}-\mathrm{O}) ;{ }^{1} \mathrm{H}$ NMR (DMSO- $\left.d_{6}\right) \delta / \mathrm{ppm}=1.67\left(\mathrm{q}, 2 \mathrm{H}, \mathrm{CH}_{2}\right), 2.75$ $\left(\mathrm{t}, 2 \mathrm{H}, \mathrm{CH}_{2}-\mathrm{SO}_{3}\right), 3.51\left(\mathrm{t}, 2 \mathrm{H}, \mathrm{CH}_{2}-\mathrm{N}^{+}\right), 3.70\left(\mathrm{~s}, 2 \mathrm{H}, \mathrm{CH}_{2}\right.$ of benzyl protons), 7.01-7.24 (m, 5H, Ar-H), 8.31 (d.d, 1H, CH), 8.53 (d, $1 \mathrm{H}, \mathrm{CH}), 8.74$ (d.d, $1 \mathrm{H}, \mathrm{CH}), 9.01$ (d, $1 \mathrm{H}, \mathrm{CH}) ;{ }^{13} \mathrm{C}$ NMR (DMSO$\left.d_{6}\right) \delta / \mathrm{ppm}=22.60,28.82,39.00,51.87,59.61,125.78,126.46$, 128.72, 129.80, 145.74, 146.82, 151.39; MS: (m/z, \%) $291\left(\mathrm{M}^{+}, 16\right)$, 243 (40\%), 201 (63\%), 124 (57\%), 114 (100\%), 96 (62\%), 71 (72\%). Anal. calcd for $\mathrm{C}_{15} \mathrm{H}_{17} \mathrm{NO}_{3} \mathrm{~S}$ (291): C, 61.94; H, 5.72; N, 4.81\%. Found: C, 61.92; H, 5.70; N, 4.82\%.

\section{Preparation of cyanine dye derivatives}

3-(2-((E)-2-((E)-2-Chloro-3-((phenylamino)methylene)cyclohex-1en-1-yl)-1-phenylvinyl)pyridine-1-ium-1-yl)propane-1-sulfonate (4). A mixture of salt $2(2.91 \mathrm{~g}, 10 \mathrm{mmol})$, anilinium salt 3 (3.23 g, 10 $\mathrm{mmol})$ and anhydrous sodium acetate $(0.82 \mathrm{~g}, 10 \mathrm{mmol})$ was stirred under reflux for $5 \mathrm{~h}$ in $n$-butanol and benzene $(7: 3)$ under $\mathrm{N}_{2}$ atmosphere. The solution was evaporated under reduced pressure. The collected solid product was rinsed using diethyl ether and dried to afford compound 4.

Yield 68\%; reddish brown crystals; mp $198{ }^{\circ} \mathrm{C}$; IR (KBr): Ú/ $\mathrm{cm}^{-1}=3351(\mathrm{NH}), 3010(\mathrm{Ar}-\mathrm{H}), 2976\left(\mathrm{CH}_{2}\right), 1617(\mathrm{C}=\mathrm{N}), 1600$ $(\mathrm{C}=\mathrm{C}), 759(\mathrm{C}-\mathrm{Cl}) ;{ }^{1} \mathrm{H}$ NMR $\left(\mathrm{DMSO}-d_{6}\right) \delta / \mathrm{ppm}=1.25(\mathrm{~m}, 2 \mathrm{H}$, $\mathrm{C} 5-\mathrm{H}_{2}$ of cyclohexenyl ring), $1.67\left(\mathrm{~m}, 2 \mathrm{H}, \mathrm{CH}_{2}\right), 1.91(\mathrm{t}, 4 \mathrm{H}, \mathrm{C} 4-$ $\mathrm{H}_{2}$ and $\mathrm{C} 6-\mathrm{H}_{2}$ of cyclohexenyl ring), $2.13\left(\mathrm{t}, 2 \mathrm{H}, \mathrm{CH}_{2}-\mathrm{SO}_{3}\right), 3.65$ $\left(\mathrm{t}, 2 \mathrm{H}, \mathrm{CH}_{2}-\mathrm{N}^{+}\right), 6.11(\mathrm{~s}, 1 \mathrm{H},=\mathrm{CH}), 7.11(\mathrm{~s}, 1 \mathrm{H},=\mathrm{CH}), 7.40-7.62$ (m, 10H, Ar-H), 8.41 (d.d, 1H, CH of pyridinium ring), 8.63 (d, $1 \mathrm{H}, \mathrm{CH}$ of pyridinium ring), 8.86 (d.d, $1 \mathrm{H}, \mathrm{CH}$ of pyridinium ring), 8.96 (d, 1H, CH of pyridinium ring), 10.51 (br s, $1 \mathrm{H}, \mathrm{NH}$, $\mathrm{D}_{2} \mathrm{O}$ exchangeable); ${ }^{13} \mathrm{C}$ NMR (DMSO- $\left.d_{6}\right) \delta / \mathrm{ppm}=22.81,27.75$, $29.79,29.00,52.82,60.06,117.30,119.82,122.66,125.62$, 125.96, 127.66, 128.20, 129.61, 130.91, 136.54, 141.00, 141.13, 143.30, 144.87, 146.40; MS: (m/z, \%) $520\left(\mathrm{M}^{+}+2,23 \%\right), 483$ (55\%), 403 (19\%), 311 (32\%), 269 (42\%), 204 (100\%), $179(64 \%)$, 166 (18\%); Anal. calcd for $\mathrm{C}_{29} \mathrm{H}_{29} \mathrm{~N}_{2} \mathrm{O}_{3} \mathrm{SCl}(52)$ : C, 66.85; H, 5.61 ; N, 5.38\%. Found: C, 66.85; H, 5.58; N, 5.35\%.

3-((Z)-2-((E)-2-(2-Chloro-3-((E)-2-phenyl-2-(1-(3-sulfonatopropyl)pyridin-1-ium-2-yl)vinyl)cyclohex-2-en-1-ylidene)-1-phenylethylidene)pyridin-1(2H)-yl)propane-1-sulfonate (5). Pathway 1: in a round-bottomed flask fitted with an air condenser, a mixture of quaternary salt 2 (5.82 g, $20 \mathrm{mmol})$, anilinium salt 3 (3.23 g, $10 \mathrm{mmol})$, and anhydrous sodium acetate $(1.23 \mathrm{~g}, 15 \mathrm{mmol})$ was stirred under reflux for $3.5 \mathrm{~h}$ in absolute ethanol and acetic anhydride under $\mathrm{N}_{2}$ atmosphere. The reaction mixture was poured onto ice-cold water. The resulting powder was filtered, recrystallized from absolute ethanol and dried to afford compound $\mathbf{5}$.

Pathway 2: in boiling pyridine, a mixture of compound 2 $(2.91 \mathrm{~g}, 10 \mathrm{mmol})$ and carbocyanine dye 4 (5.2 g, $10 \mathrm{mmol})$ was heated under reflux in the presence of nitrogen gas for $3 \mathrm{~h}$ at $150{ }^{\circ} \mathrm{C}$. The solvent was evaporated under reduced pressure. The resulting crystals were collected, washed with absolute ethanol and petroleum ether, and dried to form compound $\mathbf{5 .}$
Yield 74\%; red crystals; mp $187^{\circ} \mathrm{C}$; IR (KBr): Ú $/ \mathrm{cm}^{-1}=3186$ $(\mathrm{Ar}-\mathrm{H}), 3099\left(\mathrm{CH}_{2}\right), 1538(\mathrm{C}=\mathrm{N}), 1532(\mathrm{C}=\mathrm{C}), 794(\mathrm{C}-\mathrm{Cl}) ;{ }^{1} \mathrm{H}$ NMR $\left(\mathrm{DMSO}-d_{6}\right) \delta / \mathrm{ppm}=1.25\left(\mathrm{~m}, 2 \mathrm{H}, \mathrm{C} 5-\mathrm{H}_{2}\right.$ of cyclohexenyl ring), $1.67\left(\mathrm{q}, 4 \mathrm{H}, 2 \mathrm{CH}_{2}\right), 1.79\left(\mathrm{t}, 4 \mathrm{H}, \mathrm{C} 4-\mathrm{H}_{2}\right.$ and $\mathrm{C} 6-\mathrm{H}_{2}$ of cyclohexenyl ring), $2.11\left(\mathrm{t}, 4 \mathrm{H}, 2 \mathrm{CH}_{2}-\mathrm{SO}_{3}\right), 2.74\left(\mathrm{t}, 2 \mathrm{H}, \mathrm{CH}_{2}-\mathrm{N}\right)$, $4.10\left(\mathrm{t}, 2 \mathrm{H}, \mathrm{CH}_{2}-\mathrm{N}^{+}\right), 4.40(\mathrm{~s}, 1 \mathrm{H},=\mathrm{CH}), 6.24$ (d.d, $1 \mathrm{H}, \mathrm{CH}$ of pyridine ring), $6.36(\mathrm{~s}, 1 \mathrm{H},=\mathrm{CH}), 6.60(\mathrm{~d}, 1 \mathrm{H}, \mathrm{CH}$ of pyridine ring), 6.61 (d, 1H, CH of pyridine ring), 6.95 (d.d, 1H, CH of pyridine ring), 7.31 (d.d, 1H, $\mathrm{CH}$ of pyridinium ring), 7.51-7.60 (m, 12H, Ar-H), 7.80 (d.d, $1 \mathrm{H}, \mathrm{CH}$ of pyridinium ring); ${ }^{13} \mathrm{C} \mathrm{NMR}$ $\left(\right.$ DMSO- $\left.d_{6}\right) \delta / \mathrm{ppm}=22.18,23.63,25.47,27.23,30.00,30.18$, $51.37,51.87,60.10,108.58,113.47,122.10,122.45,125.24$, 125.49, 126.69, 127.218, 128.78, 129.33, 136.85, 138.42, 141.00, 141.32, 144.53, 145.70, 147.21; MS: (m/z, \%) $720\left(\mathrm{M}^{+}+2,15\right), 720$ (34\%), 640 (25\%), 603 (29\%), 651 (54\%), 481 (60\%), 439 (39\%), 362 (26\%), 285 (100\%), 142 (53\%), 117 (45\%), 92 (40\%); Anal. calcd for $\mathrm{C}_{38} \mathrm{H}_{38} \mathrm{~N}_{2} \mathrm{O}_{6} \mathrm{~S}_{2} \mathrm{Cl}$ (718): C, 63.54; H, 5.33; N, 3.90\%. Found: C, 63.53; H, 5.34; N, 3.89\%.

\section{General procedure for the synthesis of cyanine dyes 6 and 8}

In a round-bottomed flask fitted with an air condenser, 0.01 mole of piperazine and 1,6-hexadiol with 0.01 mole of compound $\mathbf{5}$ in $N, N$-dimethylformamide and anhydrous sodium hydroxide was heated under reflux in the presence of $\mathrm{N}_{2}$ gas for $5 \mathrm{~h}$ at $150{ }^{\circ} \mathrm{C}$. The reaction mixture was cooled and poured onto ice-cooled water. The precipitated solid was collected by filtration and recrystallized from absolute ethanol, affording compounds 6 and 8.

3-(2- $((E)-1-P h e n y l-2-((E)-3-((Z)-2-$ phenyl-2-(1-(3-sulfonatopropyl)pyridin-2(1H)-ylidene)ethylidene)-2-(piperazin-1yl)cyclohex-1-en-1-yl)vinyl)pyridin-1-ium-1-yl)propane-1sulfonate (6). Yield 98\%; red crystals; mp $213{ }^{\circ} \mathrm{C}$; IR ( $\left.\mathrm{KBr}\right)$ : Ú $/ \mathrm{cm}^{-1}=3453(\mathrm{NH}), 3101(\mathrm{Ar}-\mathrm{H}), 2954\left(\mathrm{CH}_{2}\right), 1637(\mathrm{C}=\mathrm{N})$, $1562(\mathrm{C}=\mathrm{C}) ;{ }^{1} \mathrm{H}$ NMR (DMSO- $\left.d_{6}\right) \delta / \mathrm{ppm}=1.90(\mathrm{~m}, 2 \mathrm{H}, \mathrm{C} 5-$ $\mathrm{H}_{2}$ of cyclohexenyl ring), $2.11\left(\mathrm{q}, 4 \mathrm{H}, 2 \mathrm{CH}_{2}\right), 1.79(\mathrm{t}, 4 \mathrm{H}$, C4 $-\mathrm{H}_{2}$ and $\mathrm{C} 6-\mathrm{H}_{2}$ of cyclohexenyl ring), 3.00-3.21 (m, $8 \mathrm{H}$, $\left.2 \mathrm{CH}_{2}-\mathrm{SO}_{3}, 2 \mathrm{CH}_{2}-\mathrm{N}\right), 4.10\left(\mathrm{t}, 4 \mathrm{H}, 2 \mathrm{CH}_{2}-\mathrm{N}\right.$ of piperazine ring), $4.30\left(\mathrm{t}, 2 \mathrm{H}, \mathrm{CH}_{2}-\mathrm{N}^{+}\right), 6.20(\mathrm{~s}, 1 \mathrm{H},=\mathrm{CH}), 6.50(\mathrm{~s}, 1 \mathrm{H}$, $=\mathrm{CH}), \quad 7.51-7.60 \quad(\mathrm{~m}, 18 \mathrm{H}, \quad \mathrm{Ar}-\mathrm{H}$, pyridine $-\mathrm{H}$ and pyridinium-H), $12.10(\mathrm{~s}, 1 \mathrm{H}, \mathrm{NH}) ;{ }^{13} \mathrm{C}$ NMR (DMSO- $\left.d_{6}\right) \delta /$ $\mathrm{ppm}=23.52,24.32,27.13,30.00,31.21,51.38,52.87$, $61.10,109.57,112.34,121.10,121.45,125.34,126.49$, $126.62,127.212,128.75,129.63,136.75,138.22,141.10$, 141.52, 144.23, 145.71, 147.28; MS: $(\mathrm{m} / z, \%) 767\left(\mathrm{M}^{+}, 85\right)$, 682 (34\%), 602 (25\%), 651 (54\%), 481 (60\%), 439 (39\%), 362 (26\%), 285 (100\%), 142 (53\%), 117 (45\%), 92 (40\%); Anal. calcd for $\mathrm{C}_{42} \mathrm{H}_{47} \mathrm{~N}_{4} \mathrm{O}_{6} \mathrm{~S}_{2}$ (767): C, 65.69; H, 6.17; N, 7.30\%. Found: C, 65.67; H, 6.19; N, 7.32\%.

3- $((Z)-2-((E)-2-(2-((6-H y d r o x y h e x y l) o x y)-3-((E)-2-p h e n y l-$ 2-(1-(3-sulfonatopropyl)pyridin-1-ium-2-yl)vinyl)cyclohex2-en-1-ylidene)-1-phenylethylidene)pyridin-1(2H)-yl) propane-1-sulfonate (8). Yield 48\%; reddish brown crystals; mp $213{ }^{\circ} \mathrm{C}$; IR (KBr): Ú $/ \mathrm{cm}^{-1}=3356(\mathrm{OH}), 3101(\mathrm{Ar}-\mathrm{H})$, $2953\left(\mathrm{CH}_{2}\right), 1606(\mathrm{C}=\mathrm{N}), 1600(\mathrm{C}=\mathrm{C}) ;{ }^{1} \mathrm{H}$ NMR $\left(\mathrm{DMSO}-d_{6}\right)$ $\delta / \mathrm{ppm}=0.8-1.20\left(\mathrm{~m}, 8 \mathrm{H}, 4 \mathrm{CH}_{2}\right), 1.70-1.91\left(\mathrm{~m}, 6 \mathrm{H}, 3 \mathrm{CH}_{2}\right.$ of cyclohexenyl ring), 2.40-2.81 (m, $12 \mathrm{H}, 2 \mathrm{CH}_{2}, 2 \mathrm{CH}_{2}-\mathrm{SO}_{3}$, 
$\left.2 \mathrm{CH}_{2}-\mathrm{N}, \mathrm{CH}_{2}-\mathrm{N}^{+}\right), 4.70\left(\mathrm{t}, 2 \mathrm{H}, \mathrm{CH}_{2}-\mathrm{O}\right), 5.00(\mathrm{t}, 2 \mathrm{H}, \mathrm{OH})$, $6.34(\mathrm{~s}, 1 \mathrm{H},=\mathrm{CH}), 6.85(\mathrm{~s}, 1 \mathrm{H},=\mathrm{CH}), 7.00-8.31(\mathrm{~m}, 18 \mathrm{H}$, Ar-H, pyridine- $\mathrm{H}$ and pyridinium- $\mathrm{H}), 11.63(\mathrm{~s}, 1 \mathrm{H}, \mathrm{OH}) ;{ }^{13} \mathrm{C}$ NMR (DMSO- $\left.d_{6}\right) \delta / \mathrm{ppm}=23.57,24.00,26.23,31.10,32.24$, $52.38,52.87,61.10,109.47,112.31,121.14,123.45,125.34$, $126.459,126.67,128.21,128.76,129.61,134.75,133.22$, 140.13, 142.53, 143.23, 144.71, 146.18; MS: $(\mathrm{m} / z, \%) 799$ $\left(\mathrm{M}^{+}, 75\right), 719$ (34\%), 639 (25\%), 597 (54\%), 555 (60\%), 454 (39\%), 438 (26\%), 361 (100\%), 284 (53\%), 217 (45\%), 152 (40\%); Anal. calcd for $\mathrm{C}_{42} \mathrm{H}_{47} \mathrm{~N}_{4} \mathrm{O}_{6} \mathrm{~S}_{2}$ (799): C, 66.06; $\mathrm{H}$, 6.43 ; N, 3.50\%. Found: C, 66.03; H, 6.40; N, 3.48\%.

\section{General methodology for the synthesis of carbocyanine dyes 7} and 9

Pathway 1: under nitrogen gas, a mixture of $0.02 \mathrm{~mol}$ of piperazine and 1,6-hexadiol and $0.01 \mathrm{~mol}$ of compound 5 was refluxed in a two-necked round-bottomed flask fitted with an air condenser in $\mathrm{N}, \mathrm{N}$-dimethylformamide and anhydrous sodium hydride $(0.025 \mathrm{~mol})$ for $5 \mathrm{~h}$. The reaction content was allowed to cool overnight and was then poured onto ice-cold water and acidified with dil. HCl. The isolated solid was collected by filtration and purified by column chromatography with $\mathrm{CH}_{2}$ $\mathrm{Cl}_{2}$ : hexane $(3: 1)$ to afford compounds 7 and 9.

Pathway 2: under nitrogen gas, a mixture of $0.01 \mathrm{~mol}$ of compound 5 and $0.01 \mathrm{~mol}$ of compounds 6 and 8 was refluxed in a two-necked round-bottomed flask fitted with an air condenser in $N, N$-dimethylformamide and anhydrous sodium hydride $(0.025 \mathrm{~mol})$ for $5 \mathrm{~h}$. The reaction mixture was allowed to cool overnight and then poured onto ice-cold water and acidified with dil. $\mathrm{HCl}$. The isolated solid was collected by filtration and purified by column chromatography with $\mathrm{CH}_{2} \mathrm{Cl}_{2}$ : hexane (3:1) to afford compounds 7 and 9.

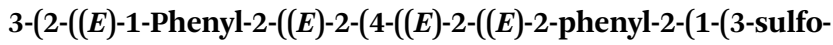
natopropyl)pyridin-1-ium-2-yl)vinyl)-6-((Z)-2-phenyl-2-(1-(3-sulfonatopropyl)pyridin-2(1H)-ylidene)ethylidene)cyclohex-1-en-1yl)piperazin-1-yl)-3-((Z)-2-phenyl-2-(1-(3-sulfonatopropyl)pyridin-2(1H)-ylidene)ethylidene)cyclohex-1-en-1-yl)vinyl)pyridin1-ium-1-yl)propane-1-sulfonate (7). Yield 47\%; brown crystals; mp $254{ }^{\circ} \mathrm{C}$; IR (KBr): Ú/cm ${ }^{-1}=3261(\mathrm{Ar}-\mathrm{H}), 3057\left(\mathrm{CH}_{2}\right), 1597$ $(\mathrm{C}=\mathrm{N}), 1541(\mathrm{C}=\mathrm{C}) ;{ }^{1} \mathrm{H}$ NMR $\left(\mathrm{DMSO}-d_{6}\right) \delta / \mathrm{ppm}=1.10-1.50(\mathrm{~m}$, $2 \mathrm{H}, \mathrm{C} 5-\mathrm{H}_{2}$ of cyclohexenyl ring, $8 \mathrm{H}, 4 \mathrm{CH}_{2}, 4 \mathrm{H}, \mathrm{C} 4-\mathrm{H}_{2}$ and $\mathrm{C} 6-$ $\mathrm{H}_{2}$ of cyclohexenyl ring), $1.89\left(\mathrm{~s}, 4 \mathrm{H}, 2 \mathrm{CH}_{2}-\mathrm{N}\right.$ of piperazine ring), $2.10\left(\mathrm{t}, 2 \mathrm{CH}_{2}-\mathrm{N}\right), 3.02\left(\mathrm{t}, 8 \mathrm{H}, 4 \mathrm{CH}_{2}-\mathrm{SO}_{3}\right), 4.17(\mathrm{t}, 4 \mathrm{H}$, $\left.2 \mathrm{CH}_{2}-\mathrm{N}^{+}\right), 5.72(\mathrm{~s}, 1 \mathrm{H},=\mathrm{CH}), 6.41(\mathrm{~s}, 1 \mathrm{H},=\mathrm{CH}), 6.71-8.25(\mathrm{~m}$, $36 \mathrm{H}, \mathrm{Ar}-\mathrm{H}$, pyridine-H and pyridinium- $\mathrm{H}), ;{ }^{13} \mathrm{C}$ NMR (DMSO- $d_{6}$ ) $\delta / \mathrm{ppm}=25.51,26.31,27.23,30.80,33.28,50.37,52.12,59.10$, 108.52 , 111.37, 122.11, 121.45, 124.34, 125.49, 12.62, 127.71, 128.76, 129.61, 135.75, 137.22, 140.12, 142.52, 143.23, 144.71, 148.28; Anal. calcd for $\mathrm{C}_{80} \mathrm{H}_{84} \mathrm{~N}_{6} \mathrm{O}_{12} \mathrm{~S}_{4}$ (1449): C, 66.28; $\mathrm{H}$, 5.84; N, 5.80\%. Found: C, 66.27; H, 5.82; N, 5.78\%.

3-(2-)(E)-1-Phenyl-2- $((E)-2-((6-)((E)-2-((E)-2-$ phenyl-2-(1-)(3-sulfonatopropyl)pyridin-1-ium-2-yl)vinyl)-6-((Z)-2-phenyl-2-(1-(3sulfonatopropyl)pyridin-2(1H)-ylidene)ethylidene)cyclohex-1en-1-yl)oxy)hexyl)oxy)-3-((Z)-2-phenyl-2-(1-(3-sulfonatopropyl) pyridin-2(1H)-ylidene)ethylidene)cyclohex-1-en-1-yl)vinyl) pyridin-1-ium-1-yl)propane-1-sulfonate (9). Yield 35\%; red crystals; $\mathrm{mp}>300{ }^{\circ} \mathrm{C}$; IR $(\mathrm{KBr}): \mathrm{U} / \mathrm{cm}^{-1}=3098(\mathrm{Ar}-\mathrm{H}), 2916$ $\left(\mathrm{CH}_{2}\right), 1576(\mathrm{C}=\mathrm{N}), 1535(\mathrm{C}=\mathrm{C}) ;{ }^{1} \mathrm{H}$ NMR (DMSO- $\left.d_{6}\right) \delta / \mathrm{ppm}=$ 0.7-1.30 (m, $\left.8 \mathrm{H}, 4 \mathrm{CH}_{2}\right), 1.80\left(\mathrm{t}, 8 \mathrm{H}, 4 \mathrm{CH}_{2}\right.$ of cyclohexenyl ring), $1.83\left(\mathrm{t}, 4 \mathrm{H}, 2 \mathrm{CH}_{2}\right.$ of cyclohexenyl ring), $2.49\left(\mathrm{t}, 8 \mathrm{H}, 4 \mathrm{CH}_{2}-\mathrm{N}\right)$, 2.40-2.93 (m, 8H, 4CH $\left.-\mathrm{CO}_{3}\right), 4.71\left(\mathrm{t}, 8 \mathrm{H}, 4 \mathrm{CH}_{2}-\mathrm{N}^{+}\right), 5.1(\mathrm{t}, 4 \mathrm{H}$, $\left.2 \mathrm{CH}_{2}-\mathrm{O}\right), 6.10(\mathrm{~s}, 1 \mathrm{H},=\mathrm{CH}), 6.55(\mathrm{~s}, 1 \mathrm{H},=\mathrm{CH}), 6.80-8.40(\mathrm{~m}$, $36 \mathrm{H}, \mathrm{Ar}-\mathrm{H}$, pyridine-H and pyridinium-H); ${ }^{13} \mathrm{C}$ NMR (DMSO- $d_{6}$ ) $\delta / \mathrm{ppm}=21.14,23.10,25.43,30.12$, 32.26, 50.18, 52.84, 60.12, $110.47,114.31,120.14,124.41,125.64,127.45,127.67,128.28$, 128.71, 129.43, 133.15, 136.22, 141.13, 142.59, 153.13, 154.71, 156.18; Anal. calcd for $\mathrm{C}_{82} \mathrm{H}_{88} \mathrm{~N}_{4} \mathrm{O}_{14} \mathrm{~S}_{4}$ (1481): C, 66.46; $\mathrm{H}$, 5.99; N, 3.78\%. Found: C, 66.46; H, 5.99; N, 3.78\%.

\section{Preparation of dye-sensitized $\mathrm{Cu} / \mathrm{TiO}_{2}$}

Wet impregnation was used to prepare $\mathrm{Cu} / \mathrm{TiO}_{2} \cdot 1 \mathrm{~g}$ of $\mathrm{TiO}_{2}$ (P25) was mixed with $3 \mathrm{ml}$ of a solution of copper nitrate $\left(\mathrm{Cu}\left(\mathrm{NO}_{3}\right)_{2}\right)$ under ultrasonication. The slurry was dried in air overnight at $120{ }^{\circ} \mathrm{C}$ and then calcined at $500{ }^{\circ} \mathrm{C}$. Then, $0.5 \mathrm{~g}$ of $\mathrm{Cu} / \mathrm{TiO}_{2}$ was stirred with a mixture of dye and anhydrous ethanol for $24 \mathrm{~h}$ in the dark and then filtered, washed with ethanol and dis. water, and dried at $100{ }^{\circ} \mathrm{C}$ for $4 \mathrm{~h}$.

\section{Photo- and sonocatalytic hydrogen production}

The water splitting reaction was carried out in a closed circulation quartz reactor system at room temperature and under atmospheric pressure. The system was bubbled with nitrogen for $20 \mathrm{~min}$ to remove unwanted gases, such as air or oxygen. In the experiment, $0.1 \mathrm{~g}$ of the catalyst was dispersed by a magnetic stirrer in $100 \mathrm{ml}$ water, and methanol was used as a sacrificial agent. During the experiment, and under constant stirring, the reaction mixture was irradiated by a $500 \mathrm{~W}$ Xe lamp. The concentration of the evolved hydrogen was measured using an Agilent GC 7890A system equipped with a thermal conductivity detector (TCD) using argon as a carrier gas. The experiments were repeated in the presence of ultrasonic waves; a Ti probe connected to an ultrasonic wave generator was immersed in the mixture to investigate the samples sonophotocatalytically.

\section{Conclusion}

Derivatives of cyanine-sensitized $\mathrm{Cu} / \mathrm{TiO}_{2}$ were prepared, characterized, and investigated in hydrogen production. The cyanine dyes played significant roles in enhancing the photoactivity of metal-loading metal oxides due to their high absorbance intensity and chemical stability. The dye molecules adsorbed on the surface of $\mathrm{Cu} / \mathrm{TiO}_{2}$ served as an initiator in the photocatalysis process rather than $\mathrm{TiO}_{2}$. The transfer of the excited electrons from the dye molecules to $\mathrm{TiO}_{2}$ and then to the loaded $\mathrm{Cu}$ inhibits the recombination of $\mathrm{e}^{-} / \mathrm{h}^{+}$pairs despite the small surface area. Combining ultrasound waves with photo irradiation remarkably increased the rate of hydrogen production over the dye-sensitized $\mathrm{Cu} / \mathrm{TiO}_{2}$. Sonophotocatalysis is a useful technique for high energy conversion efficiency; it supports continuous dispersion of the particles in the reactor and contributes to the formation of powerful radical species. 
The optimum amount of photocatalyst was $0.14 \mathrm{~g}$. Above this amount, the rate of hydrogen production decreased.

\section{Conflicts of interest}

The authors declare that there is no conflict of interest.

\section{Acknowledgements}

The authors are deeply grateful to the Deanship of Scientific Research at Umm Al-Qura University, which supported this work financially (Grant no 15SCI-3-3-0024).

\section{Notes and references}

1 A. Fujishima and K. Honda, Nature, 1972, 238(5358), 37.

2 T. Feng, et al., Int. J. Photoenergy, 2014, 1.

3 R. Lamba, et al., Talanta, 2015, 131, 490-498.

4 X. F. Lei, X. X. Xue and H. Yang, Appl. Surf. Sci., 2014, 321, 396.

5 M. Bellardita, et al., Chem. Phys., 2007, 339(1-3), 94.

6 D. Chen, et al., Appl. Surf. Sci., 2013, 284, 921.

7 W. Chen, et al., Appl. Surf. Sci., 2018, 445, 527.

8 K.-H. Chung, et al., Int. J. Hydrogen Energy, 2018, 43(24), 11422.

9 G. Malekshoar and A. K. Ray, Chem. Eng. Sci., 2016, 152, 35.

10 H.-Y. Lin and C.-y. Shih, J. Mol. Catal. A: Chem., 2016, 411, 128.

11 K. Villa, et al., Sol. Energy, 2012, 86(1), 558.

12 J.-H. Yan, et al., J. Alloy. Comp., 2009, 472(1), 429.

$13 \mathrm{~J} . \mathrm{Li}$, et al., Int. J. Hydrogen Energy, 2013, 38(25), 10746.

14 L. Sang, et al., Int. J. Hydrogen Energy, 2017, 42(50), 29686.

15 Y. Yuan, et al., Chem. Eng. J., 2015, 27, 8.

16 M. Anpo and M. Takeuchi, J. Catal., 2003, 216, 505.

17 N. L. Wu and M. S. Lee, Front. Chem. Sci. Eng., 2004, 29(15), 1601.

18 S. Xu, et al., Int. J. Hydrogen Energy, 2010, 35(11), 5254.

19 Y. Zou, et al., Int. J. Hydrogen Energy, 2014, 39(28), 1540315410.

20 D. Gao, et al., ACS Sustain. Chem. Eng., 2019, 7(11), 1008410094.

21 W. Chen, et al., Mater. Res. Bull., 2019, 116, 16-21.

22 A. A. Nada, et al., Int. J. Hydrogen Energy, 2008, 33(13), 3264.

23 H. J. Snaith, Adv. Funct. Mater., 2010, 20(1), 13.

24 J. Burschka, et al., Nature, 2013, 499(7458), 316.
25 A. Levitz, F. Marmarchi and M. Henary, Molecules, 2018, 23(2), 226.

26 T. L. Dost, M. T. Gressel and M. Henary, Anal. Chem. Insights, 2017, 12, 1177390.

27 C. P. Toseland, J. Chem. Biol., 2013, 6(3), 85.

28 X. Liu, Z. Xu and J. M. Cole, J. Phys. Chem. C, 2013, 117(32), 16584.

29 R. E. El-Mekawy and A. A. Fadda, Bioorg. Med. Chem. Lett., 2018, 28(10), 1747.

30 R. E. El-Mekawy and A. A. Fadda, RSC Adv., 2017, 7(86), 54706.

31 H. Hyun, et al., Angew. Chem., Int. Ed. Engl., 2015, 54(30), 8648.

32 M. Ahmad, et al., Ultrason. Sonochem., 2014, 21(2), 761.

33 S. Anandan and M. Ashokkumar, Ultrason. Sonochem., 2009, 16(3), 316.

34 S. Chakma and V. S. Moholkar, Ultrason. Sonochem., 2015, 22, 287.

35 H. Harada, C. Hosoki and A. Kudo, J. Photochem. Photobiol. A Chem., 2001, 141(2-3), 219.

36 H. Harada, Ultrason. Sonochem., 2001, 8(1), 55.

37 C. G. Joseph, et al., Ultrason. Sonochem., 2009, 16(5), 583.

38 A. A. Fadda and R. E. El-Mekawy, Dyes Pigments, 2013, 99(2), 512.

39 N. M. M. Hamada and E. M. Sharshira, Molecules, 2011, 16(3), 2304.

40 I. Timtcheva, et al., J. Photochem. Photobiol. A Chem., 2000, 130(1), 7.

41 S. Ko, et al., Mater. Sci. Eng., B, 2010, 166, 127.

42 V. Vinesh, A. R. M. Shaheer and B. Neppolian, Ultrason. Sonochem., 2019, 50, 302.

43 P. L. Gentili, et al., Int. J. Hydrogen Energy, 2009, 34(22), 9042.

44 H. Guo, et al., Electrochim. Acta, 2014, 120, 23.

45 S. Nachimuthu, et al., Phys. Chem. Chem. Phys., 2016, 18(2), 1071.

46 G. Janssens, et al., Chem. Phys. Lett., 2001, 344(1), 1.

47 X.-j Yang, et al., Trans. Nonferrous Metals Soc. China, 2015, 25(2), 504.

48 A. A. Nada, et al., Int. J. Hydrogen Energy, 2005, 30(7), 687.

49 A. Tiwari and U. Pal, Int. J. Hydrogen Energy, 2015, 40(30), 9069.

50 X. Wang, K. Shih and X. Y. Li, Water Sci. Technol., 2010, 61(9), 2303.

51 A. Mehta, et al., New J. Chem., 2017, 41, 4573. 